\title{
Hepatotoxin Microcystin-LR Extraction Optimization
}

\author{
Maria Estela Silva-Stenico, ${ }^{a}$ Romeu Cantúsio Neto, ${ }^{b}$ Ivânio R. Alves, ${ }^{b}$ Luiz Alberto B. Moraes, ${ }^{c}$ \\ Tânia K. Shishido ${ }^{a}$ and Marli Fátima Fiore ${ }^{*, a}$
}

${ }^{a}$ Centro de Energia Nuclear na Agricultura (CENA), Universidade de São Paulo, CP 96, 13400-970 Piracicaba-SP, Brazil

${ }^{b}$ Sociedade de Abastecimento de Água e Saneamento (SANASA), Laboratório Central, Rua Abolição, 2375, Swift, 13045-610 Campinas-SP, Brazil

'Departamento de Química, Faculdade de Filosofia, Ciências e Letras de Ribeirão Preto, Universidade de São Paulo, Av. Bandeirantes, 3900, Ribeirão Preto-SP, Brazil

\begin{abstract}
Vários gêneros de cianobactérias produzem metabólitos secundários tóxicos, entre eles as hepatotoxinas microcistinas. A análise de microcistinas em águas para abastecimento humano é uma exigência do Ministério da Saúde (Portaria 518/2004), mas essa portaria ainda não estabelece o método de extração e análise a serem usados e a quantificação da toxina é comumente realizada por ELISA ("enzyme-linked immunosorbent assay") ou HPLC (cromatografia líquida de alta eficiência), cuja eficiência depende do método de extração utilizado. Neste trabalho foi desenvolvido um método simples, rápido e barato de extração para o isolamento e identificação de microcistinas. Para isso, selecionou-se a linhagem Microcystis aeruginosa NPLJ-4 descrita como produtora de microcistina-LR. Oito diferentes tratamentos foram testados para determinar a melhor extração da toxina. As amostras foram analisadas por LC-MS (cromatografia líquida acoplada a espectrometria de massas), ELISA e Q-TOF (“quadrupole time-of-flight"). Os resultados mostraram que a melhor extração foi a que usou sonicação das amostras diluídas em água. O método proposto permite o processamento rápido das amostras e estabelece um método de extração para análise e identificação de microcistina-LR e outras variantes.
\end{abstract}

Several cyanobacterial genera produce toxic secondary metabolites, the most well-known of which are the hepatotoxic microcystins (MCYSTs). Microcystin analyses in drinking water are a requirement of the Health Ministry (Regulation 518/2004) in Brazil, but this regulation does not establish which extraction and analytical method should be used; toxin quantification is usually carried out by ELISA (enzyme-linked immunosorbent assay) or HPLC (high performance liquid chromatography), the efficiency of which depends on the extraction method used. In this work a simple, fast and cheap method of extraction was developed for the isolation and identification of MCYSTs. For this, the strain Microcystis aeruginosa NPLJ-4, reported to be a MCYST-LR producer, was selected. Eight different treatments were tested to determine the best MCYST extraction. Samples were applied in LC-MS (liquid chromatography-mass spectrometry), ELISA and Q-TOF (quadrupole time-of-flight). The most efficient extraction was achieved by sonicating samples diluted in water. The proposed method permits rapid sample processing, and establishes an extraction method for both the analysis and identification of MCYST-LR and other variants.

Keywords: LC-MS, Q-TOF, Microcystis aeruginosa, microcystin

\section{Introduction}

Toxic cyanobacterial blooms in freshwater bodies used as sources for human consumption, recreation and irrigation are becoming more frequent due to the

*e-mail: fiore@cena.usp.br eutrophication of these environments. Monitoring toxinproducing strains is important to prevent adverse effects on human and animal health caused by their toxins. Rapid and sensitive methods for the detection of these cyanotoxins that can be used in water supply stations and watershed-monitoring programs are of fundamental interest. 
Microcystins (MCYSTs) are cyclic heptapeptides, synthesized by the multifunctional enzymes termed peptide synthetase and polyketide synthase, through a non-ribosomal pathway. ${ }^{1-3}$ These toxins are found in all cyanobacterial orders, ${ }^{4,5}$ but most studies have been developed almost exclusively in planktonic ones. There are more than 70 known variants of MCYSTs, ${ }^{6,7}$ all of which possess the cyclical structure D-alanineX-D-MeAsp-Z-Adda-D-glutamate-Mdha, ${ }^{8}$ where Adda is the 3-amino-9-methoxy-2,6,8,-trimethyl-10-phenyldeca-4,6dienoic acid, D-MeAsp is the D-erythro- $\beta$-methyl-aspartic acid and Mdha is N-methyldehydroalanine. Structural modifications to the Adda region or acylation of the glutamate play an important role in toxicity. ${ }^{9}$ Microcystin molecular masses vary between 500 and 4,000 Da. ${ }^{10}$ In the MCYST molecule, $\mathrm{X}$ and $\mathrm{Z}$ are responsible for about $25 \%$ of variable $\mathrm{L}$-amino acids that contribute to the different isoforms (Figure 1). ${ }^{11,12}$ The variable amino acid residue $\mathrm{X}$ is commonly leucine (L), arginine (R), or tyrosine $(\mathrm{Y})$, while $\mathrm{Z}$ is usually arginine $(\mathrm{R})$ or alanine $(\mathrm{A})$ (Table 1). These toxic peptides inhibit protein phosphatase 1 and $2 \mathrm{~A}$ in eukaryotes in a specific and irreversible way.

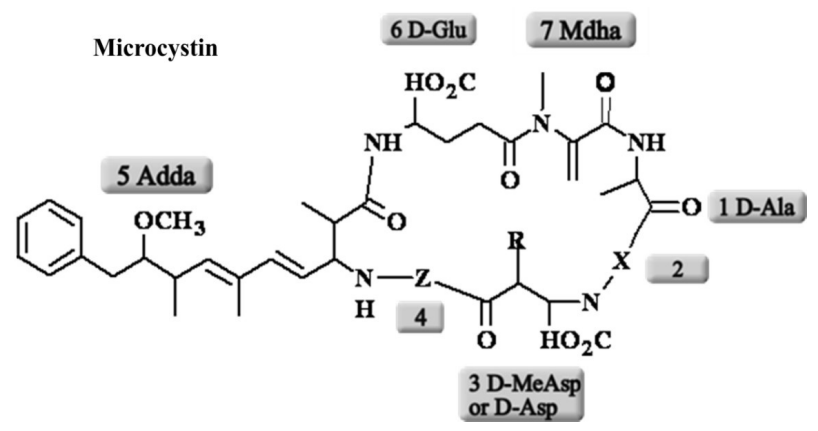

Figure 1. Chemical structure of MCYST. X(2) and Z(4) are two amino acid variables.

Monitoring cyanobacteria in waters used for human consumption is considered to be a priority by the World Health Organization (WHO). The WHO has stipulated that the tolerable maximum concentration of MCYST in drinking water is $1.0 \mu \mathrm{g} \mathrm{L}^{-1}$. In Brazil, the same MCYST value in drinking water was established through Regulation 518/2004 of Ministry of Health. Tolerable values for other cyanotoxins are still being discussed. Hence, there is an urgent need for the administrative organs responsible for monitoring water quality destined for human consumption to predict the formation of toxic blooms and monitor their development. However, the monitoring is complex, since morphological analyses using optical microscopy cannot differentiate toxic blooms from non-toxic ones. ${ }^{13,14}$ Thus, direct analysis of the toxins is required. Direct methods for toxin detection include bioassays using mice, enzymelinked immunosorbent assay (ELISA), biochemical assays that depend on inhibition of enzymatic activities, analytic
Table 1. Examples of the amino acid composition of MCYST variants

\begin{tabular}{llll}
\hline Microcystin & $\mathrm{X}$ & $\mathrm{Z}$ & $\mathrm{m} / \mathrm{z}$ \\
\hline Microcystin-LA & Leu & Ala & 910 \\
Microcystin-LL & Leu & Leu & 952 \\
Microcystin-AR & Ala & Arg & 953 \\
Microcystin-YA & Tyr & Ala & 960 \\
Microcystin-LM & Leu & Met & 970 \\
Microcystin-VF & Val & Phe & 972 \\
Microcystin-YM & Tyr & Met & 972 \\
Microcystin-LF & Leu & Phe & 986 \\
Microcystin-LR & Leu & Arg & 995 \\
Microcystin-LY & Leu & Tyr & 1002 \\
Microcystin-LW & Leu & Trp & 1025 \\
Microcystin-FR & Phe & Arg & 1029 \\
Microcystin-RR & Arg & Arg & 1038 \\
Microcystin-YR & Tyr & Arg & 1045 \\
Microcystin-WR & Trp & Arg & 1068 \\
\hline
\end{tabular}

high performance liquid chromatography (HPLC) and mass spectrometry. ${ }^{15}$ Although these techniques have limitations, which include time-consuming and laborious protocols, they provide an accurate measure of the toxin concentration. However, the major concern after choosing the appropriated method for toxin detection is the extraction step due to problems with cell disruption and the choice of solvent, which vary greatly. This may occur because the number of microcystin variants that can be found in samples and the chemical characteristics of each toxin play an important role in its extraction. To overcome this problem, it is necessary to adjust the extraction procedure to extract all MCYSTs present in a sample before starting the analysis.

The aim of this study was to develop a simple, fast and economical method for MCYST extraction that can be used in LC-MS, ELISA and Q-TOF analysis. The identification of two MCYST variants produced by M. aeruginos $a$ NPLJ-4 was also performed.

\section{Experimental}

\section{Selected strain and growth conditions}

The Brazilian isolate Microcystis aeruginosa NPLJ-4 (obtained from Sandra M.F.O. Azevedo from the Instituto de Biofísica Carlos Chagas Filho, Centro de Ciências da Saúde, Universidade Federal do Rio de Janeiro) was cultivated in $8 \mathrm{~L}$ of ASM-1 liquid medium. ${ }^{16}$ Culture was sparged with sterile air and maintained at $23{ }^{\circ} \mathrm{C}$ under constant illumination by white fluorescent light (40 $\mu$ mol photon $\mathrm{m}^{-2} \mathrm{~s}^{-1}$ ) for 20 days. 


\section{MCYST extraction}

After cyanobacterial growth, the cultures were centrifuged at $3,000 \times \mathrm{g}$ at $4{ }^{\circ} \mathrm{C}$. The cells were lyophilized and used for MCYST extraction. Eight different extraction treatments were investigated in order to determine the best. A total of $0.02 \mathrm{~g}$ of lyophilized cells was used in each MCYST extraction method tested. MCYSTs were extracted according to the following treatment methods. Treatment A: $2 \mathrm{~mL}$ of $100 \%$ methanol were added to the cells and the solution was stirred for $1 \mathrm{~h}$. The extract was centrifuged $(10,000 \times \mathrm{g}$ for $15 \mathrm{~min})$ and the supernatant collected. The pellet obtained was re-extracted according to the same procedure. The supernatants were combined and evaporated to dryness $\left(40{ }^{\circ} \mathrm{C}\right)$. The dried material was stored at $-20^{\circ} \mathrm{C}$ until use. Treatment B: $2 \mathrm{~mL}$ of $5 \%$ acetic acid were added to the cells and the solution was stirred for $1 \mathrm{~h}$. The extract was centrifuged $(10,000 \times \mathrm{g}$ for $15 \mathrm{~min}$ ) and the supernatant collected. The pellet obtained was re-extracted according to the same procedure. The supernatants were combined and evaporated to dryness $\left(40{ }^{\circ} \mathrm{C}\right)$. The dried material was stored at $-20{ }^{\circ} \mathrm{C}$ until use. Treatment $C: 2 \mathrm{~mL}$ of water were added to the cells. The solution was boiled in a microwave for $1 \mathrm{~min}$. The extract was centrifuged $(10,000 \times \mathrm{g}$ for $15 \mathrm{~min})$ and the supernatant collected. The pellet obtained was re-extracted according to the same procedure. The supernatants were combined and lyophilized. The dried material was stored at $-20{ }^{\circ} \mathrm{C}$ until use. Treatment $D$ : $2 \mathrm{~mL}$ of $100 \%$ methanol $+0.1 \%$ trifluoroacetic acid (TFA) were added to the cells and the solution was stirred for $1 \mathrm{~h}$. The extract was centrifuged $(10,000 \times \mathrm{g}$ for $15 \mathrm{~min})$ and the supernatant collected. The pellet obtained was re-extracted according to the same procedure. The supernatants were combined and evaporated to dryness $\left(40{ }^{\circ} \mathrm{C}\right)$. The dried material was stored at $-20{ }^{\circ} \mathrm{C}$ until use. Treatment E: $2 \mathrm{~mL}$ of $100 \%$ methanol were added to the cells. The solution was subjected to sonic disruption for 3 min. The pellet obtained was re-extracted according to the same procedure. The supernatants were combined and evaporated to dryness $\left(40{ }^{\circ} \mathrm{C}\right)$. The dried material was stored at $-20{ }^{\circ} \mathrm{C}$ until use. Treatment $F: 2 \mathrm{~mL}$ of water were added to the cells and incubated for $30 \mathrm{~min}$ under liquid nitrogen, followed by $30 \mathrm{~min}$ in a water bath at $45{ }^{\circ} \mathrm{C}$. The extract was centrifuged $(10,000 \times \mathrm{g}$ for $15 \mathrm{~min}$ ) and the supernatant collected. The pellet obtained was re-extracted according to the same procedure. The supernatants were combined and lyophilized. The dried material was stored at $-20{ }^{\circ} \mathrm{C}$ until use. Treatment $G: 2 \mathrm{~mL}$ of water were added to the cells. The solution was subjected to a pressure of $4 \mathrm{kgf} \mathrm{cm}^{-2}\left(\mathrm{~N}_{2}\right)$ in a cell disruptor for $3 \mathrm{~min}$. The extract was centrifuged $(10,000 \times \mathrm{g}$ for $15 \mathrm{~min}$ ) and the supernatant collected. The pellet obtained was re-extracted according to the same procedure. The supernatants were combined and lyophilized. The dried material was stored at $-20{ }^{\circ} \mathrm{C}$ until use. Treatment $H$ : $2 \mathrm{~mL}$ of water were added to the cells. The solution was submitted to sonic disruption for $3 \mathrm{~min}$. The pellet obtained was re-extracted according to the same procedure. The supernatants were combined and lyophilized. The dried material was stored at $-20{ }^{\circ} \mathrm{C}$ until use.

$25 \mu \mathrm{L}$ of microcystin-LR solution containing $5 \mu \mathrm{g} \mathrm{L}^{-1}$ of toxin were added to one of the samples (Treatment $C$ ) as an internal standard. Duplicate injections of the standard addition solution were also analyzed to allow calculation of the sample recovery.

All the treatments were performed in triplicate and amber glasses flasks were used during the extraction process.

\section{LC-MS analysis}

All the chemicals and solvents used were of either analytical or HPLC grade. One milliliter of methanol was added to the solid extract obtained as described above. The solution was mixed for $30 \mathrm{~s}$ and left for $24 \mathrm{~h}$ at $10{ }^{\circ} \mathrm{C}$. The solution was filtered (Chromafil RC 45/25-Regenerated Cellulose $45 \mathrm{~mm}$ ), and the pellet was re-extracted twice with $1.0 \mathrm{~mL}$ of methanol while stirring for $30 \mathrm{~s}$. HPLC analysis was performed on a system consisting of a liquid chromatography (Waters, model 2695) with a photodiodearray (Waters, model 2996) coupled to a Micromass ZQ4000 quadrupolar mass spectrometer (Waters). The analytical column (Atlantis, $\mathrm{dC}_{18}, 3 \mu \mathrm{m}, 2.1 \times 150 \mathrm{~mm}$, Waters Corp.) at a flow rate of $0.30 \mathrm{~mL} \mathrm{~min}^{-1}$ and UV detection occurred at $238 \mathrm{~nm}$. Mobile phases were composed of water (A) and $2 \%$ acetonitrile (B), both containing $0.02 \%(\mathrm{v} / \mathrm{v})$ trifluoroacetic acid. A $2 \%$ to $80 \%$ acetonitrile gradient was used for $35 \mathrm{~min}$.

The toxin concentration in each sample was determined according to a standard curve (10 to $200 \mu \mathrm{g} \mathrm{L}^{-1}$ ) with pure MCYST-LR (Alexis Corporation-Lausen, Switzerland). The toxin was identified by comparing the retention time of the peak in the extract with that of the standard. Linearity with a correlation coefficient (r) of 0.998345 was obtained between peak area and concentration.

The mass spectrometer monitored the MCYST-LR ion at $\mathrm{m} / z, 995.60[\mathrm{M}+\mathrm{H}]^{+}$using the electrospray ionization (ESI) operated in the positive ion mode. Ions generated from the ESI source were introduced into the mass spectrometer through a heated capillary. Ionization of the target molecule was achieved with a capillary voltage of 
$3.5 \mathrm{kV}$ and a cone voltage of $40 \mathrm{~V}$. The desolvation and cone gas $\left(\mathrm{N}_{2}\right)$ were set at 460 and $160 \mathrm{~L} \mathrm{~h}^{-1}$, respectively, and the desolvation and source temperatures were $250{ }^{\circ} \mathrm{C}$ and $150{ }^{\circ} \mathrm{C}$, respectively. Data analysis was performed using EMPOWER computer software (Waters Corp.).

\section{Quadrupole time-of-flight MS/MS (Q-TOF)}

Mass spectrometer analysis was performed using a hybrid quadrupole time-of-flight (Q-TOF) high resolution (7.000) and high accuracy (5 ppm) Q-TOF mass spectrometer (Micromass, Manchester, UK) equipped with an electrospray ion source (ESI). The conditions for the positive ESI were as follows: desolvation gas (nitrogen) was heated at $180^{\circ} \mathrm{C}$, the capillary was held at a potential of $3.5 \mathrm{kV}$, and the cone voltage was $25 \mathrm{kV}$. MS/MS tandem mass spectra were acquired by mass-selecting the target ion using the quadrupole mass analyzer followed by a $30 \mathrm{eV}$, collision-induced dissociation (CID) using argon in the quadrupole collision cell and mass analysis by TOF. Extracts were introduced into the ion source at $5 \mu \mathrm{L} \mathrm{min}{ }^{-1}$ with a syringe pump.

\section{ELISA assay}

Toxins were extracted according to Treatment $C$ as follows: $2 \mathrm{~mL}$ of water were added to $0.02 \mathrm{~g}$ of lyophilized cells, microwaved for $1 \mathrm{~min}$, and then centrifuged for $15 \mathrm{~min}$ at $10,000 \times g$ and the supernatant collected and analyzed by an ELISA assay, using microplate kits for microcystins (Beacon Analytical Systems Inc., Portland, ME, USA) following the manufacturer's recommendations, with at least three replicates. The detection limit of this method was $0.1 \mu \mathrm{g} \mathrm{L}^{-1}$.

\section{Statistical analysis}

Statistical analysis comparing triplicates in each experiment was determined using Student's t-test, $p<0.05$.

\section{Results and Discussion}

The literature presents several techniques for MCYST extraction, the majority of which are laborious, expensive and time consuming. It is known that more than 70 MCYST variants can be found and there is still insufficient knowledge to predict the degree of toxicity of these cyanotoxins at the moment.

The choice of $M$. aeruginosa NPLJ-4 was due to the fact that this strain produces four MCYST variants, with MCYST-LR representing $80 \%$ of the total. ${ }^{17}$ In this study,

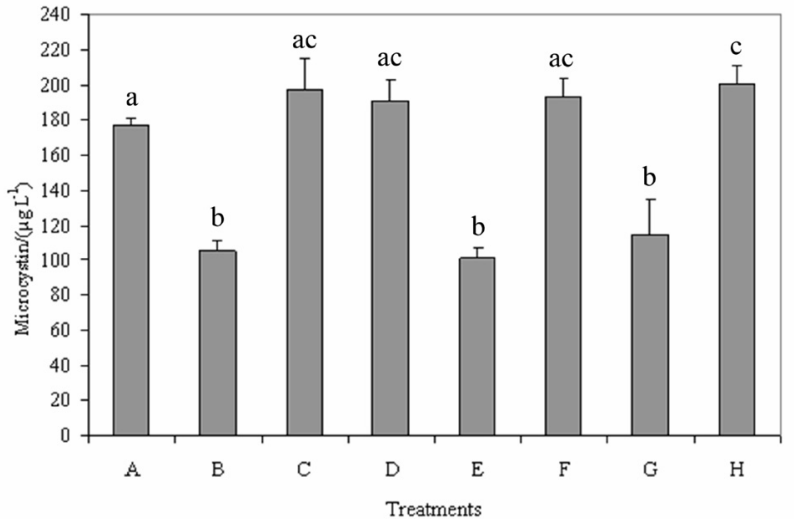

Figure 2. Comparison between treatments for MCYST-LR extraction of $M$. aeruginosa NPLJ-4. Treatments: $A$ ) methanol; $B$ ) acetic acid; $C$ ) microwave; $D$ ) methanol + TFA; E) sonic disruption + methanol; $F$ ) $\mathrm{N}_{2}$; $G$ ) cell disruptor; $H$ ) sonic disruption + water. Different letters on bars for the same treatment represent the statistical difference as determined by Student's t-test at $5 \%$ probability.

several MCYST extraction techniques found in the literature were evaluated and compared (Figure 2). Different solvents have been employed to extract MCYST. The use of 5\% acetic acid was tested by Harada et al. ${ }^{18}$ Methanol has reportedly been used, ${ }^{19,20}$ and a mix of methanol and TFA is suggested by Lawton and Edwards. ${ }^{21}$ Wicks and Thiel ${ }^{22}$ preferred to use distilled water, while Jones et al. ${ }^{23}$ used water and ultrasonication. After extraction, all of these treatments were followed by sample concentration using $\mathrm{C}_{18}$ cartridges.

The polarity of MCYSTs is a characteristic that must be considered for extraction, since polar extracts (water and methanol) showed higher contents of microcystin. ${ }^{24}$ Several solvents have been used for MCYST extractions and a consensus has yet to be reached on which is the most appropriate. Since MCYSTs are soluble in water, methanol and ethanol, but are insoluble in acetone, ether, chloroform and benzene, ${ }^{10}$ we chose eight different treatments to extract MCYST using methanol, acetic acid or water as the solvent in combination with either sonic disruption or microwave boiling.

Although statistical analysis didn't show significant differences between the treatments using sonic disruption in water, microwave boiling, methanol plus TFA, and liquid nitrogen, the most efficient extraction was obtained with the first one (Figure 2), in which cell disruptions were achieved almost completely.

Methanol is commonly used for MCYST extraction; ${ }^{25,26}$ however, we found that the use of methanol gave low yields in MCYST extraction. The use of TFA seems to have a significant effect on the extraction according to the statistical analysis. As there was no statistical significance between Treatments $C, D, F$ and $H$, it is recommended that Treatment $C$ be used for the extraction of MCYSTs 
since it preserves their structures even after several hours of boiling, ${ }^{10}$ and also because microwaves ovens are commonly found in the majority of laboratories. Our laboratory successfully applied Treatment $C$ to the analysis of toxins from several cyanobacterial genera including the branched filamentous forms and environmental samples using the ELISA kit, without any interference (data not shown), since these toxins are thermoresistant, which would facilitate monitoring in water supply stations. Although lyophilized cells were initially used, it was observed that MCYSTs could also efficiently extracted using cells collected directly from the culture. Another reason to choose Treatment $C$ is that water is used to extract MCYST, which makes the analysis by ELISA more reliable. Since ELISA is a sensitive technique for the analysis of MCYST and nodularin and it has been reported that contaminants such as methanol and plasticware, ${ }^{27}$ salinity, $\mathrm{pH}$, and metal ions ${ }^{17}$ can be responsible for false positive results, Treatment $C$ was the best choice. The other treatment methods, using methanol, acetic acid, sonic disruption using methanol and a cell disruptor, were not viable to quantify MCYST-LR or other variants using ELISA.

LC-MS was applied to obtain, in high purity, the major MCYST of M. aeruginosa NPLJ-4, which was identified as MCYST-LR based on this study (Figure 3). Treatments $B, E$ and $G$ differed between Treatments $A, C, D, F$ and $H$ to the level of significance $p<0.05$, in accordance with Student's t-test. Effective MCYST extraction from cyanobacteria requires cell disruption to release the toxin. During LC-MS analysis, the other substances released from the cell did not interfere with the determination of MCYST. The extent of recovery of MCYST-LR used as an internal standard was $98 \%$.

Mass spectrometry is considered a powerful tool for identifying toxin variants. It is a method used to study many peptides and proteins, especially complex mixtures. Q-TOF has become a very important tool, since this technique can determine and separate all types of MCYSTs, including new peptides. ${ }^{28,29}$ In addition, Q-TOF is an extremely rapid, high resolution and sensitive technique which tolerates undesirable substances and allows for the identification of toxin variants without the use of standards. Q-TOF analysis of M. aeruginosa NPLJ4 extracts identified three MCYST variants (Table 2), confirmed by ESI-MS/MS. Several MCYST variants were observed in M. aeruginosa NPLJ-4 extracts (data not shown), including protonated molecules at $\mathrm{m} / \mathrm{z}$ 953, 1002, 1025, 1042 and 1059; however, the rest of the structure could not be assigned because the ion fragmentation did not match reported masses. It is interesting that by changing the extraction treatment, such as between Treatment $A, C, D$ and $E$, the Q-TOF analysis resulted in different MCYST variants, which confirms that MCYST polarity is an important factor in their extraction (Table 2),
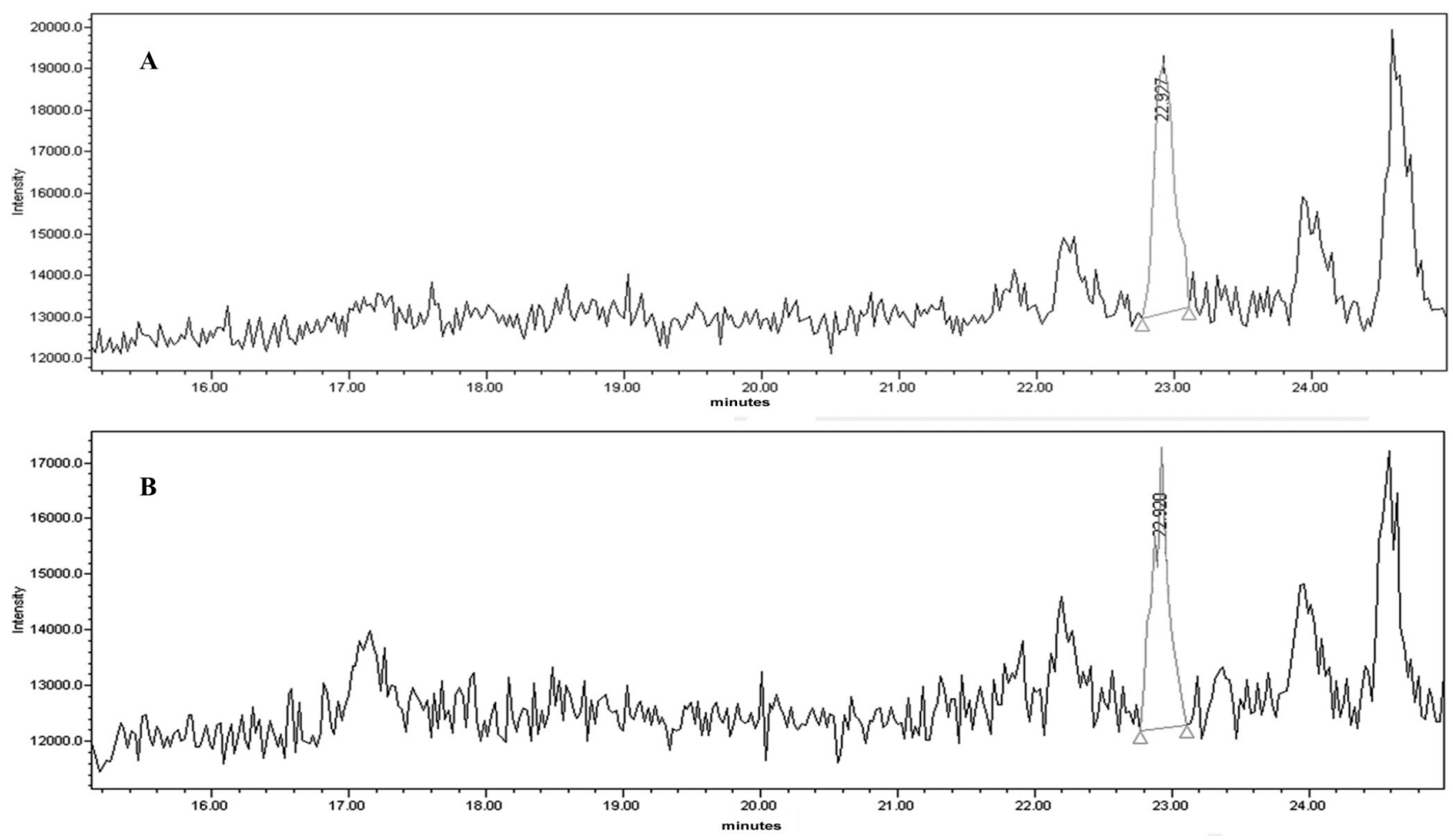

Figure 3. LC-MS chromatogram of the MCYST-LR standard (A) and M. aeruginosa NPLJ-4 extract (B). Retention times of the labeled peak correspond to the retention time of the authentic MCYST-LR standard. 
Table 2. MCYST-LR and variants found in M. aeruginosa NPLJ-4 extracts as determined by the LC-MS and Q-TOF analysis

\begin{tabular}{cccc}
\hline $\begin{array}{c}\text { MCYST } \\
\text { variant }\end{array}$ & $\begin{array}{c}{[\mathrm{M}+\mathrm{H}]^{+}} \\
(\mathrm{m} / \mathrm{z})\end{array}$ & Extraction method & $\begin{array}{c}\text { Extraction } \\
\text { treatment }\end{array}$ \\
\hline LR & 995 & All & A to H \\
{$\left[\right.$ Asp $\left.^{3}\right]-\mathrm{RR}$} & 1024 & Water boiling & $\mathrm{C}$ \\
$\mathrm{XR}$ & 1037 & $\begin{array}{c}\text { Methanol 100\% } \\
\text { Water boiling }\end{array}$ & $\mathrm{A}$ \\
& & $\begin{array}{c}\text { Methanol 100\% + TFA 0.1\% } \\
\text { Sonication in methanol 100\% }\end{array}$ & $\mathrm{D}$ \\
\hline
\end{tabular}

as occurred for the variant $\left[\mathrm{Asp}^{3}\right]-\mathrm{RR}$, which was found only in Treatment $C$ (microwave). In order to identify these cyanopeptides, the collision-induced dissociation (CID) spectra of the $[\mathrm{M}+\mathrm{H}]^{+}$ions of $\mathrm{m} / z$ 995, 1024 and 1037 were generated (Table 3). MCYST-XR at $\mathrm{m} / z 1037$ is 42 mass units higher than the MCYST-LR analogue [ADMAdda ${ }^{5}$ ]MCYST-LHar. ${ }^{30}$ According to Zweigenbaum et al., ${ }^{31}$ [ADMAdda ${ }^{5}$ MCYST-LHar presents the loss of acetic acid from the amino acid ADMAdda, giving the fragment with $m / z$ 977, whereas the fragmentation mass spectrum of MCYST-XR did not contain the $\mathrm{m} / \mathrm{z}$ 977 fragment ion. The authors were unable to confirm its structure. Thus, XR-type microcystins must contain unidentified amino acid(s), most probably in position $2 .{ }^{32}$ We could assign a partial structure of MCYST-XR, which are ADMAdda and arginine (R) according to the ion fragmentation. All of the fragmented toxin presented the Adda residue $\left[\mathrm{C}_{9} \mathrm{H}_{11} \mathrm{O}\right]^{+}$at $\mathrm{m} / \mathrm{z} 135$ (Figure 4, A and B). MCYST-XR identified in this study has the same fragmentation pattern found in the study of Oksanen et al. ${ }^{32}$ that identified the same variant produced by the cyanobacteria Nostoc sp strain IO-102-I.

Comparison of the method used in this study with other MCYST extraction methods reveals the following advantages: short duration of extraction, and lower monetary cost since the use of $\mathrm{C}_{18}$ cartridges was not required for toxin concentration. Samples prepared by this method are suitable for analysis by LC-MS, ELISA and Q-TOF. This method can be readily adapted to a laboratory routine.

Table 3. Assignment of fragment mass shown in Figure 4 for MCYST variants produced by M. aeruginosa NPLJ-4

\begin{tabular}{|c|c|c|c|}
\hline \multirow{2}{*}{ Fragment } & \multicolumn{3}{|c|}{$m / z$} \\
\hline & MCYST-LR & MCYST-[Asp $\left.{ }^{3}\right]-R R$ & MCYST-XR \\
\hline$[\mathrm{M}+\mathrm{H}]^{+}$ & 995 & 1024 & 1037 \\
\hline$[\mathrm{M}+\mathrm{H}]^{+}-\mathrm{NH}_{3}$ & & & 1020 \\
\hline$[\mathrm{M}+\mathrm{H}]^{+}-\mathrm{H}_{2} \mathrm{O}$ & & & 1019 \\
\hline$[\mathrm{M}+\mathrm{H}]^{+}-\mathrm{CO}$ & & & 1009 \\
\hline$[\mathrm{M}+\mathrm{H}]^{+}-\mathrm{COOH}$ & & & 992 \\
\hline$[\mathrm{M}+\mathrm{H}]^{+}-\mathrm{CH}_{3} \mathrm{COOH}$ & & & 977 \\
\hline$[\mathrm{M}+\mathrm{H}]^{+}-\mathrm{Ala}$ & & & 965 \\
\hline$[\mathrm{M}+\mathrm{H}]^{+}-\mathrm{MeAsp}$ & & & 908 \\
\hline$[\mathrm{M}+\mathrm{H}]^{+}-\mathrm{Glu}$ & 866 & & \\
\hline MeAsp + Arg + Adda + Glu & & & 728 \\
\hline$m / z 728-17 \mathrm{Da}$ & & & 711 \\
\hline $\mathrm{Mdha}+\mathrm{Ala}+(155)+\mathrm{MeAsp}+\mathrm{Arg}+\mathrm{OH}$ & & & 612 \\
\hline Arg + Adda + Glu & 599 & 599 & 599 \\
\hline $\mathrm{Mdha}+\mathrm{Ala}+(155)+\mathrm{MeAsp}+\mathrm{Arg}$ & & & 595 \\
\hline$m / z 599-\mathrm{CO}$ & & & 571 \\
\hline $\mathrm{Mdha}+\mathrm{Leu}+\mathrm{MeAsp}+\mathrm{Arg}+\mathrm{H}$ & 553 & & \\
\hline $\mathrm{Ala}+(155)+\mathrm{MeAsp}+\mathrm{Arg}$ & & & 512 \\
\hline Arg + Adda & & & 469 \\
\hline Adda-fragment + Glu + Mdha & 375 & 375 & 375 \\
\hline $\mathrm{Glu}+\mathrm{Dha}+2 \mathrm{H}$ & & 200 & \\
\hline Glu + Mdha + H & 213 & & \\
\hline $\mathrm{Mdha}+\mathrm{Ala}+\mathrm{H}$ & & 155 & \\
\hline Adda-fragment $\left(\mathrm{Ph}-\mathrm{CH}_{2}-\mathrm{CH}-\mathrm{OCH}_{3}\right)$ & 135 & 135 & 135 \\
\hline Arg-related ion & 70 & 70 & \\
\hline
\end{tabular}



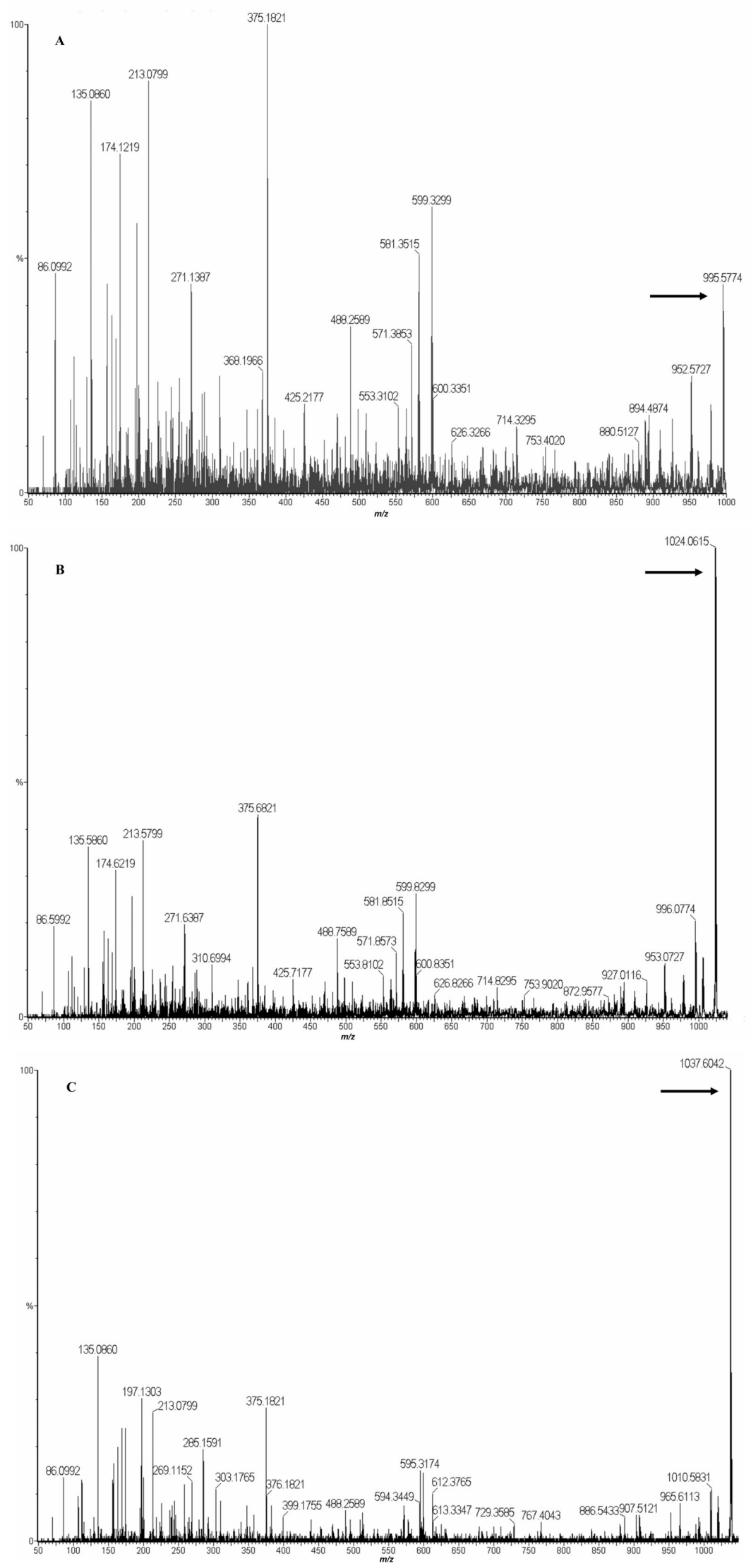

Figure 4. Fragment mass spectra of selected MCYST variants in M. aeruginosa NPLJ-4 extracts: (A) MCYST-LR; (B) MCYST-[Asp $\left.{ }^{3}\right]$-RR; (C) MCYSTXR. For assignments of amino acid sequences to $\mathrm{m} / \mathrm{z}$, see Table 3 . 


\section{Acknowledgments}

Financial support was provided by Fundação de Amparo à Pesquisa do Estado de São Paulo (FAPESP 2003/12529-4 and 2005/56303-5). M. E. Silva-Stenico was the recipient of post-doctoral fellowship from FAPESP (Grant 2004/16042-5). T. K. Shishido received an undergraduate scholarship from FAPESP (Grant 2004/16041-9). We thank Prof. Marcos N. Eberlin for Q-TOF-MS/MS analysis support in the Laboratório Thomson de Espectrometria de Massas, Instituto de Química, Universidade Estadual de Campinas, Brazil.

\section{References}

1. Nishizawa, T.; Asayama, M.; Fujii, K.; Harada, K.-I.; Shirai, M.; J. Biochem. 1999, 126, 520.

2. Nishizawa, T.; Ueda, A.; Asayama, M.; Fujii, K.; Harada, K.-I.; Ochi, K.; Shirai, M.; J. Biochem. 2000, 127, 779.

3. Tillett, D.; Dittmann, E.; Erhard, M.; von Döhren, H.; Borner, T.; Neilen, B. A.; Chem. Biol. 2000, 7, 753.

4. Honkanen, R. E.; Caplan, F. R.; Baker, K. K.; Baldwin, C. L.; Bobzin, S. C.; Bolis, C. M.; Cabrera, G. M.; Johnson, L. A.; Jung, J. H.; Larsen, L. K.; Levine, I. A.; Moore, R. E.; Nelson, C. S.; Patterson, G. M. L.; Tschappat, K. D.; Tuang, G. D.; Boynton, A. L.; Arment, A.R.; An, J.; Carmichael, W. W.; Rodland, K. D.; Magun, B. E.; Lewin, R. A.; J. Phycol. 1995, 31,478 .

5. Sivonen, K.; Jones, G. In Toxic Cyanobacteria in Water; Chorus, I.; Bartram, J., eds.; E and FN Spon: London, 1999, p. 41.

6. Spoof, L.; Vesterkvist, P.; Lindholm, T.; Meriluoto, J.; J. Chromatogr., A 2003, 1020, 105.

7. Codd, G. A.; Morrison, L. F.; Metcalf, J. S.; Toxicol. Appl. Pharmacol. 2005, 203, 264.

8. Harada, K.-I.; Imanishi, S.; Kato, H.; Mizuno, M.; Ito, E.; Tsuji, K.; Toxicon 2004, 44, 107.

9. Duy, T. N.; Lam, P. K. S.; Shaw, G.; Connell, D. W.; Rev. Environ. Contam. Toxicol. 2000, 163, 113.

10. van Apeldoorn, M. E.; van Egmond, H. P.; Speijers, G. J. A.; Bakker, G. J. I.; Mol. Nutr. Food Res. 2007, 51, 7.

11. Honkanen, R. E.; Zwiller, J.; Moore, R. E.; Daily, S. L.; Khatra, B. S.; Dukelow, M.; Boynton, A. L.; J. Biol. Chem. 1990, 265, 19401.

12. Rinehart, K. L.; Namikoshi, M.; Choi, B. W.; J. Appl. Phycol. 1994, 6, 159.

13. Komárek, J.; Algol. Stud. 1991, 64, 115.
14. Watanabe, M. In Toxic Microcystis; Watanabe, M. F.; Harada, K.-I.; Carmichael, W. W.; Fujiki, H., eds.; CRC Press: Boca Raton, 1996, p.13.

15. Frias, H. V.; Mendes, M. A.; Cardozo, K. H. M.; Carvalho, V. M.; Tomazela, D.; Colepicolo, P.; Pinto, E.; Biochem. Biophys. Res. Commun. 2006, 344, 741.

16. Gorham, P. R.; Mclachlan, J. R.; Hammer, V. T.; Kim, W. K.; Verh. Internat. Verein. Limnol. 1964, 15, 796.

17. Oliveira, A. C. P.; Magalhães, V. F.; Soares, R. M.; Azevedo, S. M. F. O.; Environ. Toxicol. 2005, 20, 126.

18. Harada, K.-I.; Matsuura, K.; Suzuki, M.; Oka, H.; Watanabe, M. F.; Oishi, S.; Dahlem, A. M.; Beasley, V. R.; Carmichael, W. W.; J. Chromatogr. 1988, 448, 275.

19. Namikoshi, M.; Rinehart, K. L.; Sakai, R.; Stotts, R. R.; Dahlem, A. M.; Beasley, V. R.; Carmichael, W. W.; Evans W. R.; J. Org. Chem. 1992, 57, 866.

20. Lawton, L. A.; Edwards, C.; Codd, G. A.; Analyst 1994, 119, 1525 .

21. Lawton, L. A.; Edwards, C.; J. Chromatogr., A 2001, 912, 191.

22. Wicks, R. J.; Thiel, P. G.; Environ. Sci. Technol. 1990, 24, 1413.

23. Jones, G. J.; Falconer, L. R.; Wilkins, R. M.; Environ. Toxicol. Water Qual. 1995, 10, 19.

24. Keil, C.; Forchert, A.; Fastner, J.; Szewzyk, U.; Rotard, W.; Chorus, I.; Kratke, R.; Water Res. 2002, 36, 2133.

25. Pelander, A.; Ojanpera, È. I.; Lahti, K.; Niinivaara, K.; Vuori, E.; Water Res. 2000, 34, 2643.

26. Spoof, L.; Vesterkvist, P.; Lindholm, T.; Meriluoto, J.; J. Chromatogr., A 2001, 909, 225.

27. Metcalf, J. S.; Hyenstrand, P.; Beattie, K. A.; Codd, G. A.; J. Appl. Microbiol. 2000, 89, 532.

28. Welker, M.; Fastner, J.; Erhard, M.; von Döhren, H.; Environ. Toxicol. 2002, 17, 367.

29. Czarnecki, O.; Henning, M.; Lippert, I.; Welker, M.; Environ. Microbiol. 2006, 8, 77 .

30. Namikoshi, M.; Rinehart, K. L.; Sakai, R.; Sivonen, K.; Carmichael, W. W.; J. Org. Chem. 1990, 55, 6135.

31. Zweigenbaum, J. A.; Henion, J. D.; Beattie, K. A.; Codd, G. A.; Poon, G. K.; J. Pharm. Biomed. Anal. 2000, 23, 723.

32. Oksanen, I.; Jokela, J.; Fewer, D. P.; Wahlsten, M.; Rikkinen, J.; Sivonen, K.; Appl. Environ. Microbiol. 2004, 70, 5756.

Received: June 26, 2008

Web Release Date: March 6, 2009

FAPESP helped in meeting the publication costs of this article. 